\title{
T-Cell Surface Glycoprotein CD8 Alpha
} Chain

National Cancer Institute

\section{Source}

National Cancer Institute. T-Cell Surface Glycoprotein CD8 Alpha Chain. NCI Thesaurus. Code C104109.

T-cell surface glycoprotein CD8 alpha chain (235 aa, $\sim 26 \mathrm{kDa}$ ) is encoded by the human CD8A gene. This protein is involved in cell-cell interactions during antigen recognition by T-cells. 